\title{
BUDIDAYA IKAN NILA PILIHAN UNTUK MENGATASI KETERGANTUNGAN PENDUDUK TERHADAP SUMBER DAYA HAYATI TAMAN NASIONAL KERINCI SEBLAT DI NAGARI LIMAU GADANG LUMPO
}

\author{
Armen \\ Jurusan Biologi Universitas Negeri Padang \\ Jl. Prof Dr. Hamka Air tawar Barat Padang. \\ Email: Armenimik@ymail.com
}

\begin{abstract}
ABSTRAK
The purpose of this research is to tilapia fish farming options to address the population's dependence on natural resources Kerinci National Park (TNKS) at Nagari Limes Tower Lumpo South Coastal District. The study involved people with the characteristics of the profession in the forest breadwinner TNKS with 40 households. In the year I conducted research information and guidance on: (1) the benefits to the ecosystem and human TNKS and the risk of making a living in TNKS; (2) create a pond breeding and rearing of tilapia; (3) the breeding and mendeder tilapia; (4) to make fish feed; (5) to collect data of economic activity conducted sample population. In II was found (1) fingerlings 25,000; (2) The rearing ponds and nursery 5 units, (3) feed production has been carried out by farmers. The findings of this study in the second year compared. Data taken form the sample frequency of visits to TNKS. The second year study lasted for 6 months. To see the similarities or differences between the mean results of economic activity used formula T-Test statistics. The results showed that the average percentage of traffic TNKS sample members for 6 months to $86 \%$. Based on research on second year level visit to the pool group members each month TNKS $75.06 \%$. The mean rate of decline in the frequency of visits to group members TNKS an approximately $11.06 \%$. Decreased levels of group members visit the pool to TNKS the second year that the guide member can mengatasai tilapia fish farming population's dependence on TNKS. Thus concluded that the tilapia fish farming has made the choice to overcome the dependence on natural resources population Kerinci National Park (TNKS) at Nagari Limes Tower Lumpo South Coastal District with fairly good results,
\end{abstract}

Key words: TNKS, Aquaculture, Tilapia, Natural Resources, Economic Activity

\section{PENDAHULUAN}

Taman Nasional Kerinci Seblat (TNKS) adalah ekosistem hutan tropis memiliki keanekaragam hayati flora tinggi. Diantara flora dan fauna merupakan jenis langka dan terancam punah serta kurang terwakili pada kawasan konservasi lain di Sumatera. Taman Nasional Kerinci Seblat merupakan sumber tangkapan air dari beberapa aliran sungai besar dan kecil sehingga sumber air dari sekitar 10 juta hektar DAS, menjadikan wilayah ini sebagai bagian dari "system penyangga kehidupan" di kawasan sekitar.Kekayaan alam dan ekosistem beserta keanekaragaman hayati di dalam TNKS memiliki arti yang sangat penting, baik sebagai penyangga kehidupan maupun sebagai sumber cadangan genetik, tempat penelitian, pendidikan dan daerah tujuan wisata.

Nagari Limau Gadang secara geografis terletak bersebelahan dengan kawasan TNKS. Jarak nagari (desa) dengan kawasan TNKS sekitar $3 \mathrm{~km}$. Nagari Limau Gadang dengan kawasan TNKS tidak dibatasi oleh kawasan penyanggah.Perladangan penduduk langsung bersatu dengan TNKS.

Nagari Limau Gadang berpenduduk sekitar 2.500 orang terdiri dari 500 kepala keluarga (KK).Sekitar 250 KK mempunyai lahan perladangan di TNKS. Ladang penduduk ditanami dengan berbagai jenis tanaman, misal kulit manis, pala, kopi, pinang, dan palawija. Kegiatan pembuatan lading bersifat menebang 
dan membakar hutan. Akibat penebangan dan pembakaran menyebabkan banyak spesies flora dan fauna terancam punah. Kegiatan ekonomi lain penduduk yang menekan hutan TNKS, adalah buruh angkut kayu olahan, mengambil kulit kayu madang keladi, mengambil manau dan mencari gaharu. Kegiatan usaha ekonomi menekan kawasan TNKS sangat maju, karena memang hutan tempat mereka menghasilkan uang untuk melangsungkan kehidupan, tanpa hutan mungkin mereka tidak bisa melangsungkan kehidupan sehari-hari. Kegiatan ekonomi berladang di luar kawasan TNKS dan menanam padi di sawah belum memadai menunjang ekonomi penduduk.

Jika ditulusuri lebih jauh,melakukan kegiatan ekonomi di kawasan TNKS bukanlah pilihan yang terbaik dan tepat, tetapi bersifat pelarian dan terpaksa untuk menyelamatkan ekonomi rumah tangga.

Jumlah kayu olahan yang diangkut penduduk setiap hari ke nagari sekitar 3 kubik manau dan kulit madang keladi sekitar 3 kubik. Pengambilan manau dan madang keladi bersifat musiman (tidak tiap hari). Kegiatan ekonomi mengambil sumberdaya hayati hutan dan berladang jelas merusak ekosistem dan memperendah tingkat keanekaragaman hayati kawasan TNKS.

Kegiatan ekonomi penduduk di kawasan TNKS Nagari Limau Gadang telah berlangsung selama 30 tahun. Akibat tekanan penduduk terhadap kawasan TNKS mengakibatkan beberapa jenis flora dan fauna mendekati kepunahan. Berdasarkan studi di lapangan, luas kawasan pengambilan kayu di TNKS telah mencapai luas sekitar 50 ha.

Melakukan kegiatan ekonomi (mencari nafkah) di TNKS berisiko tinggi karena jarak tempuh menjemput kayu ke dalam kawasan TNKS mencapai $14 \mathrm{~km}$ dan medan yang dilalui sangat berbahaya. Berdasarkan wawancara peneliti dengan 50 orang penduduk, yang melakukan kegiatan sehari-hari sebagai buruh angkut kayu olahan, semua mereka mengatakan bosan ke hutan, tetapi keadaan memaksa. Melakukan kegiatan ekonomi di desa tidak mencukupi memenuhi kebutuhan hidup. Ratarata penghasilan mereka sebagai buruh angkut kayu olahan Rp. 10.000,- per hari.

Menurut peneliti penduduk Nagari Limau Gadang bisa bertahan melakukan kegiatan ekonomi di luar TNKS jika pemerintah atau pihak peduli TNKS mampu menciptakan usaha ekonomi pilihan, misal beternak unggas, berkebun di luar TNKS dan budidaya ikan air tawar. Semua usaha ini sangat menjanjikan peningkatan ekonomi penduduk.

Salah satu bentuk usaha ekonomi yang tepat dilakukan adalah budidaya ikan nila. Secara ekonomi budidaya ikan nila sangat menguntungkan. Berdasarkan pengalaman langsung peneliti membudidayakan ikan nila dalam kolam air deras untuk 1 ton ikan kosumsi dapat diraih untung sekitar Rp. 2.000.000,dalam 3 bulan. Rata-rata penghasilan tiap hari Rp. 20.000,-, maka penggunaan pakan sendiri dapat dilakukan untuk budidaya ikan nila. Budidaya ikan nila ini bisa menjadi Model Pilihan Kegiatan Ekonomi untuk Mengurangi Ketergantungan Penduduk Nagari Limau Gadang terhadap Sumber Daya Hayati TNKS.

Tujuan dan manfaat penelitian yaitu (1) melatih penduduk sampel membudidayakan ikan nila, sehingga mereka terampil membuat kolam pendederan, kolam pembesaran, membuat pellet, dan membuat bibit; (2) penduduk sampel mencari nafkah di nagari limau gadang dengan membudidayakan ikan nila; (3) Penduduk limau gadang tidak menekan TNKS, sehingga nagari limau gadang bebas dari banjir bandang dan (4) Ekonomi penduduk limau gadang meningkat, sehinnga terwujud masyarakat sejahtera.

\section{Kemiskinan dan Kerusakan TNKS}

Kerusakan lingkungan disebabkan oleh banyak faktor, terutama ulah manusia yang tidak bersahabat dengan lingkungan sendiri. Manusia seharusnya bertanggung jawab untuk menjaga kelestarian lingkungan, tetapi mereka justru merusak lingkungan. Mereka cenderung mengambil kekayaan alam seenaknya sehingga menimbulkan kerusakan dan polusi. Setelah kekayaan alam digunakan, mereka tidak peduli terhadap kebutuhan generasi mendatang yang juga memiliki hak untuk menikmatinya. Kebutuhan seringkali mendorong manusia untuk mengambil sumber daya alam TNKS secara besar-besaran tanpa memperdulikan dampaknya. Salah satu faktor utama penyebab rusaknya lingkungan TNKS adalah kemiskinan (Ferryal 2010).

Kemiskinan secara harfiah dapat dikatakan sebagai keadaan tidak memiliki apa- 
apa secara cukup. Dalam berbagai pandangan ada tiga jenis kemiskinan yang seing dikemukakan yaitu kemiskinan struktural, kemiskinan relatif dan kemiskinan absolut. Kemiskinan struktural dimengerti sebagai kemiskinan yang timbul sebagai akibat dari kebijakan pemerintah dan perilaku korporasi yang membuat masyarakat miskin, tidak atau sedikit sekali memiliki akses terhadap ekonomi produktif. Kemiskinan relatif merupakan kemiskinan yang timbul tidak hanya dilihat dari aspek pendapatan semata namun juga keadaan hidup dalam lingkungan sosial. Sedangkan kemiskinan absolut menurut Sumodiningrat (1997) yaitu kemiskinan yang diukur dari tingkat kemampuan untuk membiayai hidup minimal sesuai dengan martabat hidup yang manusiawi.

Banyak pakar mengemukakan pendapat bahwa kemiskinan adalah salah satu penyebab utama kerusakan lingkungan di TNKS. Kerusakan lingkungan yang ditimbulkan oleh penduduk miskin cenderung dipengaruhi oleh pola pikir mereka karena mereka terhimpit oleh kemiskinan, pikiran mereka hanya terfokus pada makanan yang bisa mereka dapatkan untuk bertahan hidup hari ini. Pemikiran sempit inilah yang mendorong mereka merusak lingkungan dan merampas kekayaan alam tanpa memberikan waktu bagi alam untuk memperbarui sumber dayanya (Altin, 2007)

Perusakan hutan karena faktor kemiskinan masyarakat juga terjadi di Taman Nasional Kerinci Seblat Nagari Limau Gadang. Kerusakan Taman Nasional Kerinci Seblat diperkirakan sudah cukup parah sekitar 50 ha. Kerusakan Taman Nasional Kerinci Seblat meliputi flora, fauna dan lahan.

Kegiatan penduduk nagari Limau Gadang mencari nafkah di TNKS misal berladang, berburu dan meramu sumber daya alam hayati lain. Sebagai bukti kerusakan ekosistem TNKS Nagari Limau gadang, telah terjadi banjir bandang tahun 1997. Menurut Yusran (2011) kerusakan ekosistem TNKS bisa diatasi dengan cara alih kegiatan ekonomi. Salah satu kegiatan ekonomi yang bisa dilakukan oleh masyarakat adalah budidaya ikan air tawar, karena lahan dan sumber daya air sangat mendukung di Nagari Limau Gadang. Yusran (2011), menyatakan budidaya ikan akan bisa meningkatkan ekonomi masyarakat sehingga mereka tidak mau memasuki kawasan hutan.

Terkait dengan budidaya ikan, petani ikan mengalami kendala dalam mendapatkan pakan murah, karena harga pakan ikan cenderung meningkat. Menurut Sinaga (2013) apabila peternak menggunakan bahan pakan buatan dari pabrik, nilainya bisa mencapai $70 \%$ dari seluruh komponen biaya. Salah satu upaya yang bisa dilakukan agar budidaya ikan air tawar berhasil adalah membuat pakan sendiri. Sebagian besar bahan baku pakan ikan tersedia di Nagari Limau Gadang.

\section{Ikan Nila}

Menurut klasifikasi terbaru nama ilmiah ikan nila adalah Oerochromis niloticus. Nama genus Oerochromis menurut klasifikasi yang berlaku sebelumnya disebut dengan Tilapia. Perubahan nama tersebut telah disepakati dan dipergunakan oleh para ilmuan, meski dikalangan awam tetap disebut Tilapia nilotika. Para ahli ikan (ichtyologi) mengelompokkan genus Tilapia menjadi tiga genus berdasarkan perilaku kepedulian terhadap telur dan anakanaknya, yaitu (1) Genus Oerochromis, induk ikan betina mengerami telur di dalam rongga mulut dan mengasuh anak-anak sendiri, contohnya : Oerochromis niloticus, Oerochromis hunteri, Oerochromis anreus, dan Oerochromis spillurus: (2) Genus Sarotherodon, induk ikan jantan mengerami telur dan mengasuh anaknya, contohnya : Sarotherodon galileus dan Sarotherodon melaotheron; (3) Genus Tilapia, tidak mengerami telur dan larvanya dalam mulut induk melainkan pada suatu substrat (tempat), contohnya : Tilapia rendali dan Tilapia sparmanii.

Bentuk tubuh ikan nila pada umumya panjang dan ramping, perbandingan antara panjang dan tinggi $3: 1$, sisik ikan nila berukuran besar dan kasar, berbentuk etonoid dengan garis-garis (gurat-gurat) vertikal bewarna gelap pada sirip. Warna tubuh ikan amat bervariasi tergantung pada strain dan jenisnya. Ikan nila biasa bewarna hitam keputih-putihan sedangkan ikan nila merah bewarna merah.

Ikan nila memiliki sirip punggung dengan rumus : DXV,10 ID = Dorsolis (sirip punggung), $\mathrm{XV}=15$ duri dan $10=10$ jari-jari lemah ] dan sirip perut VI,6 [V=Vlatralis (sirip 
perut), 1 duri dan 6 jari0jari lemah]. Mata ikan nila berbentuk bulat, menonjol dan bagian tepi bewarna putih (Rukmana, 1997).

Oleh karena nila Gift merupakan ikan hasil silangan beberapa spesies unggul di beberapa negara di dunia maka sifat hidupnya sama dengan nila lokal. Nila Gift dapat hidup di perairan tawar, misal kolam, sawah, sungai, danau, rawa dan genangan dengan teknik adaptasi bertahap. Menurut Rukmana (1997) "ikan nila masih bisa tumbuh dalam keadaan asin pada kadar salinitas 0-35 permil". Djarijah (1996) mengatakan bahwa "kadar garam optimal untukl budidaya ikan nila adalah 0 - 10 permil".

Habitat ideal untuk budidaya ikan nnila adalah perairan tawar yang memiliki suhu antara $14{ }^{\circ} \mathrm{C}-38{ }^{\circ} \mathrm{C}$ atau suhu optimum $25^{\circ} \mathrm{C}-$ $30{ }^{\circ} \mathrm{C}$. Suhu terlalu rendah (kurang dari $14{ }^{\circ} \mathrm{C}$ ) dan terlalu tinggi (lebih dari $38{ }^{\circ} \mathrm{C}$ ) dapat menghambat pertumbuhan ikan nila (Rukmana, 1997).

\section{Pakan Ikan}

Setiap organisme hidup membutuhkan makanan untuk kelangsungan hidup dan pertumbuhan. Makanan bagi ikan dapat diperoleh dari alam (pakan alami) dan manusia (pakan buatan). Pakan adalah bahan yang dikonsumsi oleh hewan berfungsi sebagai sumber makanan dan sumber nutrien atau keduanya dalam ransum (makanan yang secara teratur diberikan atau dikonsumsi oleh seekor hewan) (Cruz, 1996). Hidayat, D. (1985) menyatakan bahwa " pakan yang dimakan oleh ikan energinya digunakan untuk kelangsungan hidup dan kelebihannya akan dimanfaatkan untuk pertumbuhan".

Unsur-unsur gizi yang dibutuhkan oleh ikan adalah protein, lemak, karbohidrat, vitamin dan mineral. Protein salah satu unsur yang paling penting dibutuhkan ikan untuk tenaga dan untuk pertumbuhan (Mujiman, 2000). Protein dianggap sebagai nutrien utama dalam ransum makanan sebab tidak dapat digantikan oleh unsur gizi lain misal, lemak dapat digantikan oleh karbohidrat sebagai sumber tenaga. Fungsi protein, untuk merangsang pertumbuhan ikan, pemeliharan jaringan tubuh, pembentukan enzim dan beberapa hormon tertentu, pengatur proses tertentu dalam tubuh dan sebagai sumber energi (Djajasewaka, 1985). Protein diserap dalam bentuk asam amino. Pada umumnya ikan membutuhkan protein lebih banyak daripada hewan-hewan ternak di darat (unggas dan hewan menyusui).Kebutuhan protein pada ikan berkisar antara $20-60 \%$ berat total, sedangkan kebutuhan optimum $30-36 \%$ (Mujiman, 2000).

Lemak merupakan sumber energi paling tinggi dalam pakan ikan, berfungsi menjaga keseimbangan dalam tubuh dan daya apung ikan dalam air (Djajasewaka, 1985). Kebutuhan lemak ikan berkisar antara $4-18 \%$, dengan daya guna energi dapat mencapai $85-95 \%$, sedangkan kebutuhan optimum $10-16 \%$ (Mujiman, 2000). Lemak diserap dalam bentuk tetes-tetes lemak yang terbentuk dari penggabungan trigliserida (hasil sintesis asam lemak dan gliserol), fosfolipid dan kolesterol. Kelebihan lemak akan disimpan sebagai cadangan makanan (Soewolo, 2000). Penumpukan lemak dalam jaringan tubuh ikan akan menyebabkan ikan bertambah berat.

Karbohidrat berfungsi sebagai sumber energi bagi ikan. Kebutuhan karbohidrat bagi ikan berkisar antara $15-30 \%$, untuk ikan karnivora berkisar antara $10-20 \%$ (Djajasewaka, 1985). Karbohidrat diabsorbsi dalam bentuk glukosa, fruktosa dan galaktosa. Kelebihan karbohidrat akan disimpan dalam tubuh hewan sebagai cadangan makanan dalam bentuk glikogen dalam otot (Winarno, 1997). Penimbunan glikogen dalam otot akan menyebabkan bobot ikan bertambah berat.

Vitamin berfungsi sebagai sebagian dari enzim dan koenzim, sehingga dapat juga dikatakan pengatur berbagai proses metabolisme, untuk mempertahankan fungsi berbagai jaringan tubuh, mempengaruhi pertumbuhan dan pembentukan sel-sel tertentu dalam tubuh. Kebutuhan vitamin pada ikan disesuaikan dengan kebutuhan, yaitu berkisar antara 1-2\% (Djajasewaka, 1985).

Mineral berfungsi dalam pembentukan berbagai jaringan tubuh seperti tulang, gigi dan sisik ikan. Mengatur keseimbangan asam dan basa di dalam tubuh, untuk proses osmosa antara cairan dan lingkungan, untuk proses pembekuan darah serta untuk proses metabolisme lain dalam tubuh. Kebutuhan mineral pada ikan hanya diperlukan dalam jumlah yang sedikit dan biasanya sudah tercampur dengan vitamin (Djajasewaka, 1985) 
Bahan baku yang diperlukan untuk membuat pakan ikan nila adalah konsentrat, ubi kayu, dedak halus dan premiks. Konsentrat merupakan bahan baku sumber protein yang digunakan dalam penelitian ini karena konsentrat merupakan produk pabrik yang mudah diperoleh. Konsentrat mengandung protein yang sangat tinggi dan sudah menjadi standar sebagai sumber protein untuk pakan ikan dan unggas. Jika konsentrat dapat diganti dengan ikan rucah atau keong mas yang ada di lokasi penelitian.

Ubi kayu merupakan bahan baku yang diprioritaskan dalam penelitian ini, karena mudah diperoleh belum pernah digunakan orang sebagai bahan baku pakan. Selain sebagai bahan baku, ubi kayu juga berfungsi sebagai perekat (binder) (Soetanto, 1998). Ubi kayu yang digunakan adalah berupa halusan dari ubi kayu yang telah direbus. Tujuan perebusan adalah untuk menimbulkan getah dan menghilangkan racun $\mathrm{HCN}$ yang dikandung oleh ubi kayu. Dalam daftar analisa bahan makanan yang dikeluarkan oleh Direktorat Gizi DepKes, dicantumkan bahwa gizi ubi kayu adalah protein $1,2 \%$, lemak $0,3 \%$, karbohidrat 34,7\%, air 63\% (Djaeni, 1999, hal 290).

Dedak halus merupakan hasil sampingan dari penggilingan padi, sebagian besar terdiri dari lapisan perikarp dan kulit padi. Bahan baku ini mudah diperoleh di tempat penggilingan padi dan hargamya relatif murah. Dedak yang dipilih mempunyai tekstur (btiran) halus, tidak lembab, tidak berbau apek, dan memiliki warna segar. Dedak mengandung unsur gizi : protein $11,35 \%$, lemak $12,15 \%$, karbohidrat $28,62 \%$, abu $10,5 \%$, serat kasar $24,46 \%$ dan air $10,15 \%$ (Mujiman, 2000).

Premiks merupakan bahan yang berisi vitamin dan mineral yang dbutuhkan ikan dalam ukuran tertentu. Premiks ini sudah langsung tersedia dalam kemasan dan komposisi yang telah tercantum pada labelnya. Premiks ini dapat diperoleh dengan mudah terutama di depot penjualan makanan ternak.

\section{Mekanisme Pengaruh Pakan Terhadap Pertumbuhan}

Pertumbuhan ikan merupakan perubahan ukuran ikan baik dalam bentuk bobot, panjang, volume selama waktu tertentu. Pertumbuhan ikan akan terjadi bila jumlah makanan yang dikonsumsi ikan lebih banyak daripada jumlah makana yang diperlukan untuk metabolisme dasar, pergerakan, produksi orga seksual, perawatan bagian-bagian tubuh atau mengganti sel-sel yang rusak (Efendi, 1978). Salah satu tujuan pembudidayaan ikan adalah untuk meghasilkan produk ikan sebesar mungkin dalam waktu singkat. Hal ini dapat dicapai dengan memberi pakan buatan yang mempunyai nilai gizi sesuai dengan kebutuhan ikan tersebut.

Ikan nila mempunyai bentuk badan agak memanjang pipih kesamping. Mulut (bibir) berada diujung tengah. Memiliki kumis dua pasang, kadang-kadang mempunyai sungut satu pasang, jari-jari sirip punggung yang kedua mengeras seperti gergaji, sedangkan terletak antara kedua sirip, punggung dan perut berseberangan. Sirip dada terletak dibelakang tutup insang. Ikan nila tergolong sisik besar bertipe cycloid, usus umumnya tidak begitu panjang, tidak mempunyai lambung, tidak bergigi sehingga bila mencerna makanan sebagai pengganti pengerusnya adalah dengan bagian pharing mengeras (Santoso, 1993).

Habitat ikan nila yang dibudayakan bisanya terdapat di perkolaman, dapat dikawinkan sepanjang tahun, memijah pada awal atau sepanjang musim penghujan (Santoso, 1993). Menurut Santoso (1993) ikan nila dapat tumbuh normal, jika lokasi pemeliharaan berad pada ketinggian antara 1501000 meter diatas permukaan laut, suhu air $20^{\circ}$ $\mathrm{C}-25^{\circ} \mathrm{C}, \mathrm{pH}$ air antara $7-8$.

Sumber utama oksigen untuk pernapasan adalah oksigen terlarut. Banyak oksigen terlarut tergantung pada suhu air, adanya bahan organik dan banyaknya vegetasi aquatic. Umumnya ikan nila berkembang biak pada kondisi oksigen terlarut $5 \mathrm{ppm}$. Oksigen terlarut di dalam air dipengaruhi oleh suhu, $\mathrm{pH}$ dan konsentrasi karbondioksida (Lingga, 1994: 13).

\section{METODE PENELITIAN}

Metode yang digunakan dalam penelitian ini adalah metode eksperimen dengan menunjuk 40 Kepala Keluarga (KK) sebagai sampel (responden) dari $250 \mathrm{KK}$ yang sangat tergantung mencari nafkah (melakukan kegiatan ekonomi) di kawasan TNKS. Sampel berusia 25-40 tahun. Usia 25-40 sangat 
potensial melakukan kegiatan ekonomi di TNKS karena mereka masih muda dan kuat.

Sampel dibuat menjadi 5 kelompok, tiap kelompok beranggotakan 8 orang. Setiap kelompok dibina mengelola sebuah kolam. Pengolahan meliputi pembinaan, pembuatan kolam, pembuatan pakan, pemijahan, pendederan, penebaran bibit di kolam, pemeliharaan dan pemasaran. Masa penelitian dibagi menjadi 2 tahap. Tahap pertama dibutuhkan waktu selama 6 bulan. Setelah tahap pertama selesai dilanjutkan dengan penelitian tahap kedua. Pada tahap pertama dilakukan kegiatan bimbingan membuat pakan, membuat kolam, pemijahan, pendederan, penebaran bibit ke kolam, pemeliharaan dan pemanenan. Selama penelitian tahap pertama berlangsung diambil data kegiatan ekonomi sampel di kawasan TNKS.

Data yang diambil berupa frekuensi kedatangan sampel ke dalam TNKS. Data kegiatan ekonomi sampel pada penelitian tahap pertama dibandingkan dengan data kegiatan ekonomi sampel pada penelitian tahap kedua. Penelitian tahap kedua berlangsung sekitar 6 bulan. Untuk melihat kesamaan atau perbedaan rata-rata hasil kegiatan ekonomi digunakan rumus statistika T-Test. Diharapkan pada tahap kedua kegiatan sampel tidak lagi melakukan kegiatan ekonomi di kawasan TNKS. Faktor penyebab sampel tidak melakukan kegiatan ekonomi di kawasan TNKS karena mereka telah merasakan hasil panen pertama budidaya ikan nila. Mereka dapat membandingkan hasil yang diterima dari budidaya ikan nila dengan hasil yang diterima dari melakukan kegiatan ekonomi (mencari nafkah) di kawasan TNKS.

Alur penelitian dituliskan di Gambar 1 . Berdasarkan Gambar 1 dijelaskan uraian kegiatan kegiatan penelitian adalah (1) menyuluh penduduk sampel tentang manfaat TNKS terhadap ekosistem dan manusia; (2) menyuluh resiko mencari nafkah di TNKS terhadap ekosistem dan manusia; (3) membimbing penduduk sampel menentukan dan merancang lokasi kolam; (4) membimbing penduduk sampel membuat kolam pembibitan dan pembesaran ikan nila; (5) membimbing penduduk sampel memijahkan dan mendeder ikan nila; (6) membimbing penduduk sampel membuat pakan ikan (pellet) meliputi memilih, menggodok, mencetak dan menjemur bahan baku pakan; (7) mengumpulkan data aktivitas ekonomi yang dilakukan penduduk sampel: frekuensi dan jumlah penghasilan; menganalisis data penelitian.

\section{HASIL DAN PEMBAHASAN}

Hasil penelitian memperlihatkan bahwa (1) Dihasilkan bibit ikan sebanyak 25.000 ekor ukuran $3-5 \mathrm{~cm}$, berusia 2-3 bulan tingginya jumlah yang diperoleh disebabkan anggota kelompok kolam sudah paham cara membibit dan bekerja secara serius; (2) Kolam pembesaran 5 unit, ukuran masing-masing 4x6 m; (3) Kolam pendederan 5 unit, ukurang masing-masing $15 \times 25 \mathrm{~m}$; (4) Dihasilkan pakan (pellet), hasil latihan anggota kelompok kolam. Pellet mengandung gizi standar untuk konsumsi ikan nila. Pellet bisa dibuat anggota kelompok kolam $20 \mathrm{~kg} /$ hari per orang. Jika alat pencetak pellet digerakkan oleh mesin, maka pellet bisa dihasilkan $350 \mathrm{~kg} / \mathrm{hari}$. Volume pellet yang dihasilkan akan bisa dicukupkan bila dikerjakan dengan tenaga mesin; dan (5) Bibit yang dihasilkan cukup untuk mengisi 5 buah kolam penelitian untuk dibesarkan. Setiap kolam penelitian berisi 5000 ekor bibit.

Pada aspek tingkat ketahuan anggota kelompok kolam tentang TNKS, kolam dan pakan diperoleh hasil berdasarkan survei terhadap anggota kelompok kolam, diperoleh informasi (1) Sebanyak 36 orang (90\%) anggota kelompok kolam tidak memahami manfaat TNKS (Taman Nasional Kerinci Seblat) terhadap lingkungan sekitar. Ketidaktahuan anggota kelompok kolam TNKS disebabkan tidak ada penyuluhan dari pemerintah, baik pemerintah nagari maupun pemerintah Kabupaten (2) Sebanyak 38 orang (95\%) anggota kelompok kolam tidak tahu risiko merusak Taman Nasional Kerinci Seblat (TNKS) terhadap lingkungan sektar. Tingginya persentase anggota kelompok kolam tidak tahu merusak TNKS karena mereka tidak dapat penyuluhan dari pemerintah; (3) Anggota kelompok kolam yang paham membuat kolam pendederan kolam ikan nila hanya 2 orang (5\%). Hanya sebagian kecil penduduk yang paham membuat kolam pendederan, hal ini disebabkan karena anggota kelompok kolam sehari-hari mencari nafkah di TNKS. Mereka tidak diupayakan mencari nafkah di desa mereka, misal membudidayakan ikan air tawar 
(4) Anggota kelompok kolam yang mampu membuat kolam pembesaran sekitar 5 orang (12\%). Rendahnya persentase anggota kelompok kolam yang mampu membuat kolam pembesaran disebabkan karena mereka tidak biasa membudidayakan ikan air tawar; (5)
Tidak seorang pun anggota kelompok kolam yang bisa membuat pakan ikan $(0 \%)$. Tidak adanya anggota kelompok kolam yang pandai membuat pakan ikan, disebabkan mereka tidak pernah dibimbing membuat pakan ikan dan membudidayakan ikan.

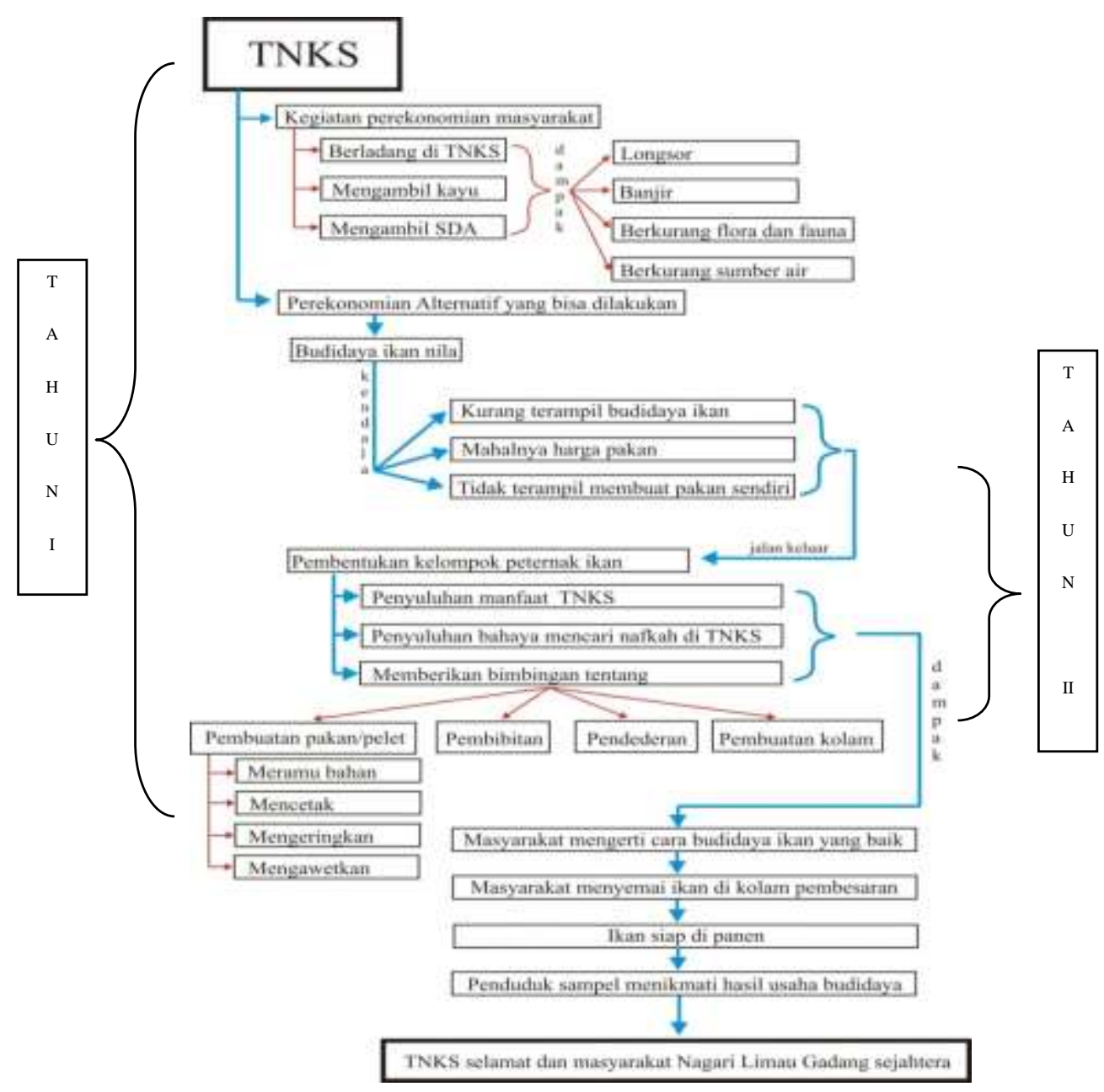

Gambar 1 Bagan Alir Penelitian

Pada tingkat kunjungan anggota kelompok kolam ke TNKS Tahun 1 diperoleh hasil rerata persentase tingkat kunjungan anggota kelompok kolam ke TNKS sebagai berikut (1) Rerata kunjungan anggota kelompok kolam ke TNKS pada bulan februari, minggu pertama adalah $84,6 \%$, kedua $88,2 \%$, ketiga $85,7 \%$, dan minggu keempat $87,5 \%$. Tingginya persentase frekuensi kunjungan anggota kelompok kolam ke TNKS, pada bulan Februari, Maret dan April disebabkan mereka belum mendapatkan hasil membudidayakan ikan nila; (2) Rerata kunjungan anggota kelompok kolam ke TNKS pada bulan maret, minggu pertama adalah $84,6 \%$, kedua $86,4 \%$, ketiga $83,9 \%$, dan minggu keempat $86 \%$ (3) 
Rerata kunjungan anggota kelompok kolam ke TNKS pada bulan april, minggu pertama adalah $83,9 \%$, kedua $84,6 \%$, ketiga $87,5 \%$, dan minggu keempat $89,2 \%$.

Tingginya persentase frekuensi kunjungan anggota kelompok kolam ke TNKS, pada bulan Februari, Maret dan April disebabkan mereka belum mendapatkan hasil membudidayakan ikan nila.

Secara keseluruhan selama 3 bulan rerata kunjungan anggota kelompok ke TNKS tiap bulan $86 \%$. Berdasarkan survei terhadap anggota kelompok kolam, diperoleh informasi (1) Sebanyak 36 orang (90\%) anggota kelompok kolam tidak memahami manfaat TNKS (Taman Nasional Kerinci Seblat) terhadap lingkungan sekitar. Ketidaktahuan anggota kelompok kolam TNKS disebabkan tidak ada penyuluhan dari pemerintah, baik pemerintah nagari maupun pemerintah kabupaten; (2) Sebanyak 38 orang (95\%) anggota kelompok kolam tidak tahu risiko merusak Taman Nasional Kerinci Seblat (TNKS) terhadap lingkungan sektar. Tingginya persentase anggota kelompok kolam tidak tahu merusak TNKS karena mereka tidak dapat penyuluhan dari pemerintah; (3) Anggota kelompok kolam yang paham membuat kolam pendederan kolam ikan nila hanya 2 orang (5\%). Hanya sebagian kecil penduduk yang paham membuat kolam pendederan, hal ini disebabkan karena anggota kelompok kolam sehari-hari mencari nafkah di TNKS. Mereka tidak diupayakan mencari nafkah di desa mereka, misal membudidayakan ikan air tawar (4) Anggota kelompok kolam yang mampu membuat kolam pembesaran sekitar 5 orang(12\%). Rendahnya persentase anggota kelompok kolam yang mampu membuat kolam pembesaran disebabkan karena mereka tidak biasa membudidayakan ikan air tawar; (5) Tidak seorang pun anggota kelompok kolam yang bisa membuat pakan ikan(0\%). Tidak adanya anggota kelompok kolam yang pandai membuat pakan ikan, disebabkan mereka tidak pernah dibimbing membuat pakan ikan dan membudidayakan ikan

Pada aspek rerata persentase tingkat kunjungan anggota kelompok kolam ke TNKS pada Tahun II diperoleh hasil sebagai berikut (1) Persentase kunjungan anggota kelompok kolam ke TNKS pada bulan april, minggu pertama adalah $76 \%$, kedua $78,6 \%$, ketiga $77,1 \%$, dan minggu keempat $77,1 \%$; (2) Persentase kunjungan anggota kelompok kolam ke TNKS pada bulan mei, minggu pertama adalah $73,6 \%$, kedua $74,6 \%$, ketiga $75 \%$, dan minggu keempat $75 \%$; (3) Persentase kunjungan anggota kelompok kolan ke TNKS pada bulan Juni, minggu pertama $74,2 \%$, kedua $76,4 \%$, ketiga $71,8 \%$, dan minggu keempat $70,7 \%$; (4) Tingginya persentase frekuensi kunjungan anggota kelompok kolam ke TNKS, pada bulan April, Mei dan Juni, disebabkan anggota kelompok kolam belum mendapatkan hasil budidaya ikan nila, sedangkan mereka harus memenuhi nafkah rumah tangga maka mereka masih harus memasuki TNKS untuk mencari nafkah; (5) Rerata kunjungan anggota kelompok kolam ke TNKS pada bulan april $77,2 \%$, bulan mei $74,7 \%$, dan pada bulan juni $73,3 \%$; (6) Frekuensi kunjungan anggota kelompok kolam ke TNKS pada bulan mei lebih rendah dibandingan bulan april. Keadaan ini menunjukan tingkat kunjungan ke TNKS mulai berkurang karena anggota kelompok kolam lebih memfokuskan untuk membudidayakan ikan nila; (7) Rerata kunjungan anggota kolam ke TNKS pada bulan juni lebih rendah dibandingankan bulan Mei. Penurunan lebih nyata pada minggu ketiga dan keempat. Penurunan kunjungan anggota kelompok kolam keTNKS pada bulan juni disebabkan oleh faktor bulan ramadhan; (8) Secara keseluruhan selama 3 bulan rerata kunjungan anggota kelompok ke TNKS tiap bulan 75,06\%.

\section{KESIMPULAN DAN SARAN}

Hasil penelitian ini adalah (1) Sebagian besar anggota kelompok kolam tidak memahami manfaat risiko dan merusak TNKS terhadap alam sekitar; (2) Kunjungan anggota kelompok kolam ke TNKS sangat tinggi; (3) Anggota kelompok kolam sudah berhasil menghasilkan bibit ikan nila untuk dibesarkan; (4) Pakan yang dibuat oleh kelompok kolam dapat digunakan untuk membesarkan bibit ikan nila; (5) Hanya sebagian kecil anggota kelompok kolam yang mampu membuat kolam. pembesaran dan pendederan; (6) Tingkat kunjungan anggota kelompok kolam pada Tahun II sudah menurun; (7) Secara keseluruhan selama 3 bulan Tahun II rerata 
kunjungan anggota kelompok ke TNKS tiap bulan 75,06\%; (8) Rerata tingkat penurunan frekuensi kunjungan anggota kelompok kolam ke TNKS sekitar $11,06 \%$.

Penelitian ini memberikan saran (1) Perlu sosialisasi secara bertahap manfaat dan risiko merusak TNKS kepada anggota kelompok kolam (2) Diupayakan mengajak anggota kolam mengurangi kunjungan ke TNKS (3) Ikan yang dideder di kolam pendederan harus dipantau setiap hari agar tidak diserang oleh hama; (4) Pakan yang dibuat harus dijemur sampai kering sebelum disimpan; (5) Bimbingan membuat kolam pembesaran dan pendederan pelu dilakukan secara intensif; (6) Pemberian pakan terhadap ikan pada kolam pembesaran harus sesuai dengan petunjuk yang telah ditetapkan.

\section{DAFTAR KEPUSTAKAAN}

Achyar, Moch dan Rismunandar.1986. Perikanan Darat. Bandung : Sinar Baru.

Afrianto, Eddy dan Liviawaty, Evi.1990. Beberapa Metode Budidaya Ikan. Yogyakarta : Kanisius.

Anonimus.1998. Pemeliharaan Ikan nila. Bandung : Sumur Bandung.

Ardiwinata, R. O. 1981. Pemeliharaan Ikan nila.Bandung : Sumur Bandung

Arie. 1999. Pemeliharaan Ikan Nila. Bandung: Sumur Bandung.

Cruz, M, Emmanuel. 1986. Buku Pegangan Latihan Makanan Ikan. Jakarta: Proyek Pengembangan Perikanan Skala Kecil.

Altin, Darus. 2007. Meningkatkan Perekonomian Masyarakat Melalui Budidaya Ikan. [online]. http: fppb.ubb.ac.id/?Page=artikel_ubb\&\&id= 184

Departemen Pertanian (BIP) Sumatera Barat. 1984-1990. Pemanfaatan Perairan Umum untuk Budidaya Ikan.Padang Departemen BIP.

Dinas Perikanan Sumatera Barat 2001. Analisa Sarana Produksi Budidaya Air Tawar Sumatera Barat. Padang : Dinas Perikanan Sumatera Barat.

Djaeni, A. 1999.Ilmu Gizi Jilid II. Jakarta : Dian Rakyat.

Farida.1988. Pengaruh Padat Penebaran Terhadap Pertumbuhan Ikan nila (Oerochromis niloticus.) yang
Dipelihara dalam Drum yang Airnya Mengalir. Padang : Fakultas Perikanan Universitas Bung Hatta.

Ferryal, Maranatha Bernard. 2010. Kemiskinan dan kerusakan Lingkungan. http: maranathabernardferryal.blogspot.com/2 010/04/kemiskinan-dan-kerusakanlingkungan.

Hidayat, Djajasekawa. 1985. Pakan Ikan (Makanan Ikan). Jakarta : Yasaguna.

Lingga, Pinus. 1994. Ikan nila Kolam Air Deras. Jakarta : Penebar Swadaya.

Mujiman.2000. Pembesaran Ikan Air Tawar Di Berbagai Lingkunagn Pemeliharaan.Jakarta : Penebar Swadaya.

Putranto, Agus. 1995 Budidaya Ikan Produktif Ikan nila. Surabaya: Karya Anda.

Rukmana. 1997. Budidaya Ikan Nila. Semarang: Aneka Semarang

Santoso, Budi. 1995. Petunjuk Praktis Budidaya Ikan nila. Kanisius: Yogyakarta.

Sinaga. 2013. Budidaya Ikan Air Tawar dapat meningkatkan ekonomi Rakyat. [online]. http:hariansemarang.net.

Soeseno, Slamet. 1982. Dasar-dasar Perikanan Umum. Jakarta Yasaguna.

Sugeng.1983. Beternak Ikan nila.Semarang : Aneka Semarang.

Sutoyo.1986. Teknik Beternak Ikan nila. Surabaya : Karya Anda.

Winarno.1997. Pakan Ikan Alami. Yogyakarta: Kanisius.

Yusran.2011. Konservasi Sumber Daya Pesisir dalam Meningkatkan Ekonomi Sumber daya alam. [online]: http: jujungbandung.com. 